\title{
ANALISIS KEMAMPUAN BERPIKIR KREATIF MATEMATIK SISWA SMP DI KABUPATEN BANDUNG BARAT PADA MATERI SEGIEMPAT DAN SEGITIGA
}

\author{
Adi Nurjaman', Hanifah ${ }^{2}$ \\ 1,2 IKIP Siliwangi Bandung \\ 11Nurjaman@stkipsiliwangi.ac.id, ${ }^{2}$ Hanifah12041996@gmail.com
}

\begin{abstract}
Thinking creative is a thinking process which to produce kinds of idea possibility and the way widely and many to completed a problem, when applied thinking creative, will produce many useful ideas on find the resolver. Creative connect with find something, about the thing that prduces something new with using something that has been there. Research methods will use is descriptive qualitative. As for the sample on this research are seventh grade with high ability, medium and low in Kabupaten Bandung Barat. For the instrument test thinking creative ability wil deliver to students are five question and following with interview in each students. Then, the results obtained was level of their thinking creative ability according to their writing test and results of interview with the low level students. Next, this research is parts of my research paper will be careful.
\end{abstract}

Keywords: Thinking Creative Math Ability, Rectangular and Triangle

\begin{abstract}
Abstrak
Berpikir kreatif adalah suatu proses berpikir yang menghasilkan bermacam-macam kemungkinan ide dan cara secara luas dan beragam dalam menyelesaikan suatu persoalan, apabila menerapkan berpikir kreatif, akan menghasilkan banyak ide yang berguna dalam menemukan penyelesaiannya. Kreatif berhubungan dengan penemuan sesuatu, mengenai hal yang menghasilkan sesuatu yang baru dengan mengunakan sesuatu yang telah ada. Metode penelitian yang digunakan adalah kualitatif deskriftif. Adapun sampel dalam penelitian ini yaitu siswa kelas VIII dengan kemampuan tinggi, sedang dan rendah di Kabupaten Bandung Barat. Adapun instrumen tes kemampuan berpikir kreatif yang diberikan sebanyak 5 soal yang disertai dengan wawancara pada masing-masing siswa. Kemudian hasil yang diperoleh adalah tingkat kemampuan berpikir kreatif siswa SMP di Kabupaten Bandung Barat berdasarkan pada tes tulis dan hasil wawancara dengan siswa masih tergolong kurang. Selanjutnya penelitian ini adalah bagian dari skripsi yang akan saya teliti.
\end{abstract}

Kata Kunci: Kemampuan Berpikir Kreatif Matematik, Segiempat dan Segitiga

How to cite: Nurjaman, A. \& Hanifah. (2018). Analisis Kemampuan Berpikir Kreatif Matematik Siswa SMP di Kabupaten Bandung Barat Pada Materi Segiempat dan Segitiga. JPMI - Jurnal Pembelajaran Matematika Inovatif, 1 (4), 467-478.

\section{PENDAHULUAN}

Pada saat ini perkembangan ilmu dan teknologi tumbuh cepat sehingga mempengaruhi kualitas sumber daya manusia. Oleh sebab itu manusia yang memiliki kemampuan berpikir kreatif, self concept dan inovatif dapat memilih, mengelola untuk dapat mengetahui informasi yang diperoleh, karena tidak semua informasi yang di dapat akan sesaui dengan kebutuhannya. Menurut Sumarmo (Purwasih, 2017) menjelaskan bahwa siswa dapat memperoleh kemampuan 
berpikir kreatif melalui pembelajaran matematika. Sejalan dengan Permendikbud No. 81A tahun 2013 tentang implementasi kurikulum pedoman umum pembelajaran dinyatakan bahwa untuk mencapai kualitas yang telah dirancang dalam dokumen kurikulum, kegiatan pembelajaran perlu menggunakan prinsip yang (1) berpusat pada peserta didik, (2) mengembangkan kreativitas peserta didik, (3) menciptakan kondisi menantang dan menyenagkan, (4) bermuatan nilai, estetika, inestetika, logika, dan etika, dan (5) menyediakan pengalaman belajar beragam melalui penerapan berbagai strategi dan metode belajar yang efisien, kontekstual, menyenangkan, bermakna, dan efektif. Penyampaian berbagai ide yang berbeda dari sesama temannya merupakan suatu tindakan berpikir kreatif yang dapat muncul dari diri siswa melalui pengetahuan kognitif (Andiyana, Maya, \& Hidayat, 2018; Dilla, Hidayat, \& Rohaeti, 2018; Hidayat, 2011; 2012; 2017; Hidayat, \& Prabawanto, 2018; Sumarmo, Hidayat, Zukarnaen, Hamidah, \& Sariningsih, 2012; Sumarmo, Mulyani, \& Hidayat, 2018; Tresnawati, Hidayat, \& Rohaeti, 2017).

Menurut (Nurjaman \& Sari, 2017) Kemampuan berpikir siswa tidak sama. Ada perbedaan dalam pola pikir siswa dari sekolah dengan kelas tinggi, sedang dan rendah, karena dari siswa kelas tinggi tersebut akan lebih baik dari siswa kelas sedang maupun rendah.

Hal tersebut senada dengan pendapat Ruseffendi (Choridah, 2013) yaitu sifat kreatif dapat tumbuh dalam diri siswa apabila seseorang tersebut dilatih, dibiasakan sejak dini untuk melakukan menjelajah, inkuiri penemuan dan pemecahan masalah.

Berdasarkan pemaparan diatas maka matematika sangat penting dipelajari oleh siswa. Hal tersebut dipertegas Sumarmo (Istianah, 2013) yakni pentingnya keterampilan berpikir kreatif dan kritis dapat dilatihkan pada siswa dengan didukung oleh visi pendidikan matematika dengan mempunyai dua arah pengembangan, visi pertama pembelajaran matematika dapat memberi arah pada pemahaman suatu konsep yang diperlukan dalam menyelesaikan permasalahan matematika dan ilmu pengetahuan lain. Visi kedua memiliki pengetian yang lebih luas, yaitu suatu pembelajaran matematika yang memberikan suatu kemampuan nalar yang logis, cermat, kritis, logis, dan sistemartis juga berpikir terbuka dan objektif, dan diperlukan dalam kehidupan sehari-hari untuk menghadapi masa depan yang selalu terus berubah dan berkembang. Adapun Indikator Kemampuan berpikir kreatif menurut Munandar (Azhari, 2013) meliputi empat kriteria, yaitu kelancaran, kelenturan atau keluwesan, keaslian dalam berpikir dan elaborasi atau keteperincian dalam mengembangkan ide atau gagasan.

Berpikir kreatif merupakan suatu pelatihan psikis untuk dapat membuahkan sesuatu yang baru dari suatu hasil pengembangan. Hal ini sesuai dengan pendapat Coleman dan Hammen Sukmadinata (Istianah, 2013) yaitu "Berpikir kreatif adalah suatu kegiatan yang bersifat psikologis untuk meningkatkan kemurnian (originality) dan ketajaman pemahaman (insight) untuk mengembangkan sesuatu (generating)". Kemampuan berpikir kreatif berkaitan erat dengan kemampuan yang dapat menghasilkan atau mengembangkan suatu hal yang baru, yaitu sesuatu kelancaran, kelenturan, keaslian dalam berpikir dan elaborasi atau keteperincian dalam mengembangkan suatu ide atau gagasan biasa yang berbeda-beda dari ide yang akan dihasilkan oleh kebanyakan orang.

Pentingnya suatu pengembangan kreativitas bagi siswa telah tertulis dalam tujuan pendidikan nasional Indonesia dan Peraturan Menteri Pendidikan Nasional nomor. 22 tahun 2006 tentang standar isi khususnya untuk pembelajaran matematika. Akan tetapi pada praktek di lapangan pengembangan kreativitas masih terabaikan. Hal tersebut sejalan dengan pemikiran Munandar (Rahman, 2012) karna masih ada sebagian sekolah yang cenderung menghambat suatu kreativitas, antara lain dengan mengeksplor kekakuan imajinasi. Masalah tersebut menjadi 
perhatian dalam sistem belajar di Indonesia dikarenakan masalah penggalian suatu kreativitas khususnya di dalam matematika masih kurang.

Berkaitan pada pentingnya kemampuan berpikir kretaif yang sesuai dengan materi segiempat maka untuk dapat menyelesaikan suatu masalah dalam kehidupan sehari-hari dengan mencetuskan banyak gagasan dalam menyelesaikan masalah. Siswa di tuntut untuk dapat menghasilkan gagasan, jawaban, ataupun pertanyaan yang bervariasi, untuk dapat melihat suatu bentuk masalah dari berbagai pandangan yang berbeda-beda dan di sajikan dalam bentuk soal cerita di dalam kehidupan sehari-hari, supaya siswa lebih merasa pembelajaran lebih bermakna dalam kehidupan yang mereka alami. Menyikapi hal tersebut maka peneliti perlu melakukan studi pendahuluan untuk mengetahui kemampuan berpikir kreatif matematik siswa SMP di Kabupaten Bandung Barat dalam materi segiempat dan segitiga

\section{METODE}

Jenis Penelitian ini tergolong ke dalam penelitian deskriptif kualitatif yang dimana tujuan untuk menjelaskan mengenai kesalahan ataupun permasalahan siswa dalam menyelesaikan suatu soal segitiga dan segiempat dilihat dari tingkat kemampuan berpikir kreatif matematik siswa SMP. Data penelitian ini berupa jawaban tertulis dan lisan yang diperoleh dari tes tertulis dan wawancara. Sampel penelitian siswa kelas VIII SMP di Kabupaten Bandung Barat dengan kemampuan tinggi, sedang dan rendah. Adapun instrumen yang diberikan pada siswa sebanyak 5 soal yang disertai dengan wawancara pada masing-masing siswa.

\section{HASIL DAN PEMBAHASAN}

\section{Hasil}

Hasil uji coba instrumen pada 3 siswa dengan kemampuan tinggi, sedang dan rendah adalah sebagai berikut:

\section{a. Analisis Soal Nomor 1}

Pertanyaan no 1 : Diketahui keliling sebuah lapangan berbentuk persegi panjang adalah $24 \mathrm{~m}$. Panjang lapangan tersebut $2 \mathrm{~m}$ lebih panjang dari lebarnya. Bagaimana cara mencari panjang dari panjang lapangan tersebut? a. Coba gambar sketsa dari permasalahan tersebut. b. Paparkan langkah-langkah penyelesaian menurut caramu sendiri!

Indikator kemampuan berpikir lancar adalah sebagai berikut:

Jawaban Siswa I (Berkemampuan tinggi):

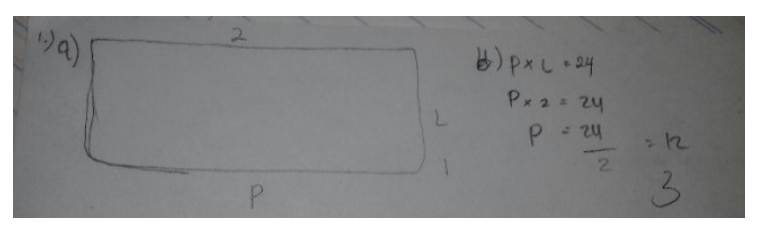

\section{Wawancara:}

G : jawaban bagian b kurang tepat. Coba amati apa maksud dari soal di atas mengenai panjang lapangan tersebut $2 \mathrm{~m}$ lebih panjang dari lebarnya, yaitu kamu tinggal mengurangi lebar dari panjang dikurangi 2, lalu kamu selesaikan ? 
S : "Oh iya bu seharusnya sesudah itu saya kurangi 2 dari panjang lebarnya".

G : "Lalu apa yang menyebabkan kamu menjawab seperti itu?"

S : "karena saya tidak bisa memahami soal yang diberikan,lalu saya lupa lagi dengan caranya."

Jawaban Siswa II (Berkemampuan sedang):

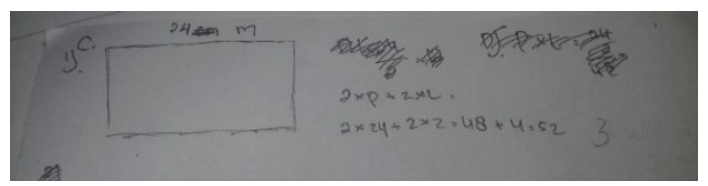

\section{Wawancara:}

G : Coba amati apa maksud dari soal yang ditanyakan mengenai panjang lapangan tersebut $2 \mathrm{~m}$ lebih panjang dari lebarnya, yaitu kamu mengurangi lebar dari panjang dikurangi 2, lalu kamu selesaikan?

S : "Oh iya bu seharusnya dikurangi 2 dari lebarnya".

G : "Lalu apa yang menyebabkan kamu mejawab seperti itu?"

S $\quad$ : “ bingung bu, gatau harus digimanain.”

Jawaban Siswa III (Berkemampuan Rendah):

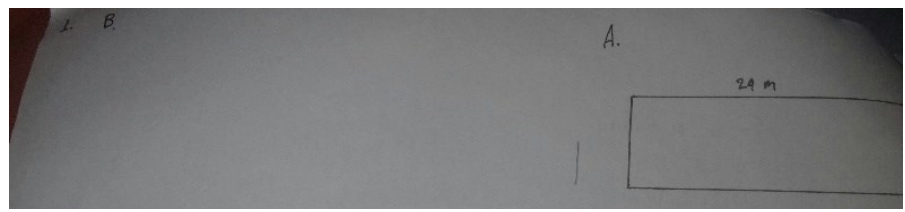

Wawancara:

G : “apakah kesulitan yang kamu dapatkan ketika akan menyelesaikan soal nomor 1, mengapa pada bagaian b kamu tidak mengisinya ?

S : "saya ngga ngerti bu, jadi saya hanya mengisi gambar sketsa saja".

Analisis:

Kesalahan siswa I dan II hampir sama yaitu siswa keliru dalam menemukan konsep mencari panjang dari panjang lapangan tersebut dan siswa kurang mencerna dengan baik mengenai soal yang ditanyakan. Namun dengan jawaban siswa I tersebut sudah hampir mendekati setengah benar. Dengan begitu siswa dapat menghasilkan banyak ide dalam suatu pemecahan masalah matematika.

Kemudian untuk siswa ke III kemampuan siswa dalam memamahi permasalahan soal masih tergolong kurang, siswa belum dapat mencetuskan banyak gagasan dalam pemecahan masalah matematika. Namun siswa sudah bisa menggambarkan sebuah sketsa dari permasalahan tersebut. 
Analisis:

Berdasarkan hasil jawaban siswa, mengenai kesalahan yang dilakukan oleh siswa adalah kurang memahami permasalahan pada soal, kurang telitinya siswa dalam perhitungan serta terdapat siswa salah dalam menentukan konsep yang akan digunakan dalam menyelesaikan soal. Dengan begitu dapat dinyatakan bahwa siswa berkemampuan tinggi, sedang dan rendah dalam indikaror berpikir lancar masih dalam tingkatan rendah.

\section{a. Analisis Soal Nomor 2}

Pertanyaan no 2 :Terdapat sebuah segitiga sama kaki ABC dan sebuah persegi panjang CDEF. Sisi CF dan persegi panjang tersebut berhimpit dengan setengah dari alas segitiga sama kaki ABC. Jika titik $G$ berada tepat di tengah sisi EF dan titik $H$ tepat di tengah sisi AF.

a. Bagaimana sketsa gambar dari pernyataan diatas?

b. Bila panjang dari $2 \mathrm{AC}=\mathrm{CF}=10 \mathrm{~cm}$, dan panjang dari $\mathrm{EF}=\mathrm{FC}=20 \mathrm{~cm}$, bagaimana caramu mencari keliling dari sebuah sketsa gambar yang telah dilakukan?

Indikator kemampuan berpikir luwes adalah sebagai berikut:

jawaban siswa 1 (Berkemampuan tinggi):

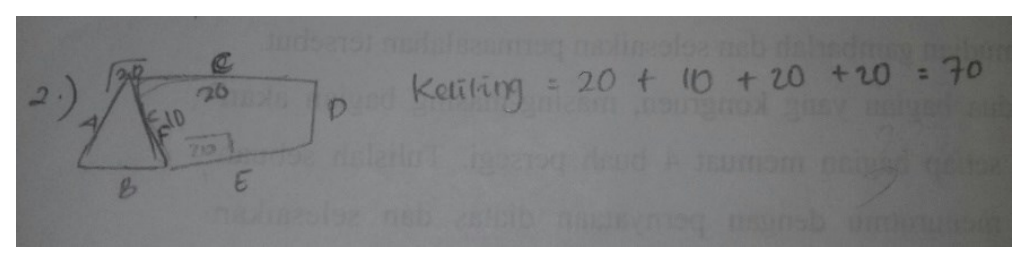

Wawancara:

G : : jawabannya kurang tepat. Sisi-sisi yang di maksud yaitu bukan $10 \mathrm{~cm}$ dan $20 \mathrm{~cm}$. Coba perhatikan jika titik $\mathrm{G}$ berada tepat di tengah sisi $\mathrm{EF}$ dan titik $\mathrm{H}$ tepat ditengah sisi $\mathrm{AF}$, maka pertama yang harus kamu cari yaitu mencari titik sisi G untuk mencari keliling tersebut?"

S : "oh iya bu, saya tidak mencerna dengan seksama soal yang ibu berikan,saya hanya terfokus pada soal bahwa sisi sisinya itu 10 dan 20 ".

Jawaban Siswa II (Berkemampuan sedang):

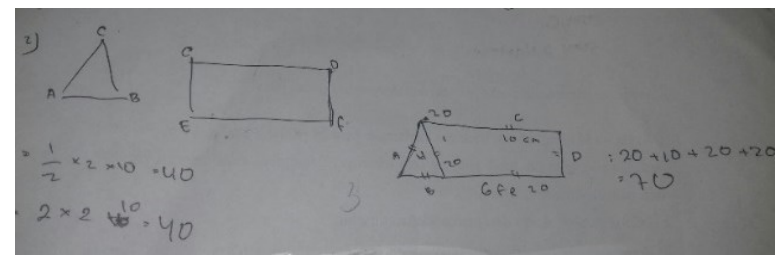

Wawancara:

G : “apakah kesulitan yang kamu dapatkan ketika akan menyelesaikan soal nomor 2, lalu mengapa kamu dapat berpendapat bahwa sisi-sisi gambar tersebut 10 dan 20?"

S : : "saya kurang teliti bu dalam memahami soal yang di maksud. pada soal bagian b saya hanya terpatok pada soal yang di berikan dan memperkirakan bahawa sisi-sisinya itu 10 dan 20." 
Jawaban Siswa (Berkemampuan Rendah):

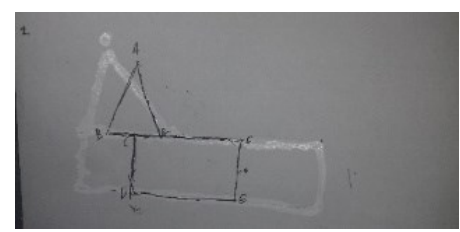

Wawancara:

G : “apakah kesulitan yang kamu dapatkan ketika akan menyelesaikan soal nomor 2?”

S : "saya tidak paham mengenai soal yang diberikan dengan ibu sehingga saya hanya mengisi sketsanya"

Kesalahan siswa I dan II hampir sama kesalahannya yaitu siswa ceroboh dalam memahami permasalahan didalam soal tersebut, siswa hanya tertuju pada soal pada soal bahwa sisi-sisinya itu 10 dan 20 sehingga siswa keliru dengan jawabannya. Dapat dilihat bahwa kemampuan siswa berpikir luwes masih dalam tingkatan rendah.

Kemudian untuk siswa ke III kemampuan dalam memahami memecahkan masalah tergolong cukup kurang, siswa hanya dapat menggambarkan sketsa itupun tidak tepat. Dapat terlihat siswa belum dapat menyajikan suatu konsep dan belum dapat menghasilkan gagasan penyelesaian dari suatu pemasalahan tersebut, maka kemampuan siswa berpikir luwes masih dalam tingkatan rendah.

Analisis:

Berdasarkan hasil jawaban siswa, maka kesalahan yang dilakukan oleh siswa yaitu kurang lengkapnya dalam pengisian jawaban, siswa ceroboh dalam memahami permasalahan pada soal, siswa tidak mencerna dengan baik pada suatu soal yang diberikan. Dengan begitu dapat disimpulakn bahwa siswa berkemampuan tinggi, sedang dan rendah dalam indikator berpikir luwes masih dalam tingkatan rendah.

\section{c. Analisis Soal Nomor 3}

Pertanyaan no 3 : Buatlah sebuah pertanyaan dalam kehidupan sehari-hari disekitarmu mengenai bentuk segitiga dan segiempat. Kemudian gambarlah dan selesaikan permasalahan tersebut.

Indikator kemampuan berpikir asli adalah sebagai berikut:

Jawaban siswa 1 (berkemampuan tinggi):

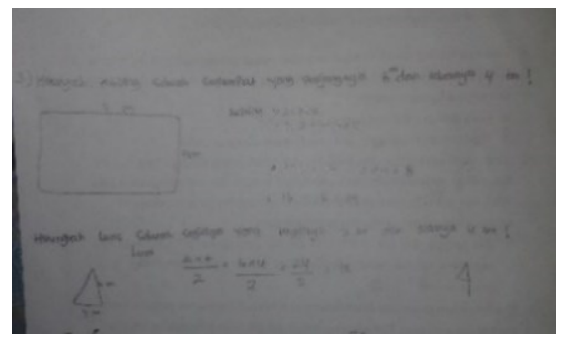

Wawancara: 
G : "apakah ada kesulitan dalam mengerjakan soal nomor 3, mengapa dalam membuat pertanyaan kamu tidak mengaitkan dengan contoh yang sudah ada disekitarmu ?"

S : " "tidak, karena soalnya menurut pendapat/pemikiran sendiri dan saya tidak mencerna dengan seksama soal yang ibu berikan,jadi saya langsung membuat soal yang tidak ada kaitannya dengan contoh disekitar saya."

Jawaban Siswa II (Berkemampuan Sedang):

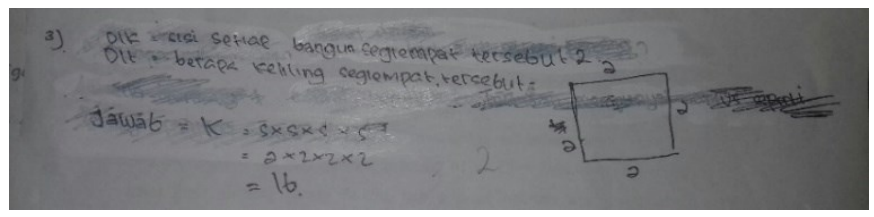

Wawancara:

G : "apakah ada kesulitan dalam mengerjakan soal nomor 3, mengapa dalam memmbuat pertanyaan kamu tidak mengaitkan dengan contoh yang ada disekitarmu dan hanya mengerjakan 1 ?"

S : "tidak, saya bisa karena menjawabnya terserah apa yang saya mau dan saya tidak mengerti, jadi saya langsung membuat dan tidak ada kaitannya dengan contoh disekitar saya, karena waktunya takut habis jadi saya hanya mengerjakan dan membuat 1 soal."

Jawaban Siswa III (Berkemampuan Rendah):

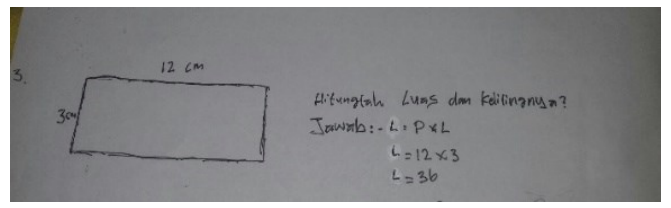

Wawancara:

G : “apakah kamu bisa dalam mengerjakan soal nomor 3, mengapa dalam memmbuat pertanyaan kamu tidak mengaitkan dengan contoh yang ada disekitarmu dan hanya mengerjakan 1 soal ?"

S : : "bisa, karena soalnya membuat sendiri jadi bisa bebas terserah saya. karena bingung maksudnya apa, jadi saya langsung membuat soal yang tidak ada kaitannya dengan contoh disekitar saya, karena takut waktunya habis"

Berdasarkan jawaban siswa I secara keseluruhan dalam menjawab saol sudah cukup tepat, adapun kesalahan yang dilakukan oleh siswa belum dapat membuat sebuah pertanyaan dengan mengaitkan pertanyaan dalam contoh yang ada disekitarnya atau dalam kehidupan sehari-hari. Dengan begitu dapat disimpulkan bahwa siswa dapat memberikan suatu ide yang baru dalam menyelesaikan masalah .

Untuk jawaban siswa dua dan tiga hampir sama kesalahannya yaitu siswa belum dapat membuat sebuah pertanyaan dengan mengaitkan pertanyaan dalam contoh yang ada disekitarnya, kesalahannya siswa hanya dapat membuat pertanyaan satu. Dapat disimpulkan bahwa kemampuan siswa berpikir secara asli masih dalam tingkatan yang rendah.

Analisis: 
Berdasarkan hasil jawaban siswa, maka kesalahan yang dilakukan oleh siswa yaitu kurang memahami dengan baik apa yang dimaksud pada soal yang diberikan, rata-rata kemampuan siswa berkemampuan tinggi, sedang dan rendah dalam menyelesaikan soal sudah cukup tepat, siswa dapat memberikan gagasan yang baru tetapi siswa belum dapat mengaitkan sebuah pertanyaan dalam kehidupan sehari-hari, maka dapat disimpulkan dalam indikator kemamapuan berpikir asli masih tergolong rendah.

\section{Analisis Soal Nomor 4}

Pertanyaan no 4 : Suatu persegi jika dibagi dua bagian yang kongruen, masing-masing bagian akan emiliki luas $64 \mathrm{~cm}^{2}$. Dan setiap bagian memuat 4 buah persegi. Tulislah sebuah pemasalahan yang serupa menurutmu dengan pernyataan diatas dan selesaikan permasalahan tersebut!

Indikator kemampuan berpikir Elaborasi adalah sebagai berikut:

jawaban siswa I (Berkemampuan tinggi):

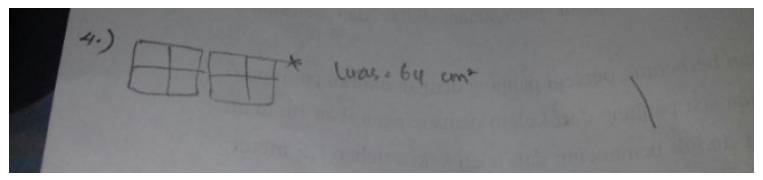

Wawancara:

G : "apakah kesulitan yang kamu dapatkan ketika akan menyelesaikan soal nomor 4, apakah sulit mengubah pertanyaan yang serupa dengan pernyataan tersebut ?"

S : "saya ragu dengan jawaban saya bu jadi saya baru menggambar-gambar, memeperkirakan jawaban. tidak bu, hanya saya kurang mencerna dengan seksama soal yang ibu berikan"

jawaban siswa (Berkemampuan sedang):

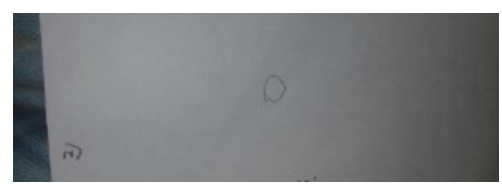

Wawancara:

G : "coba perhatikan soal ini, tulislah sebuah permasalahan yang serupa menurutmu dengan pernyataan diatas dan selesaikan, apakah sulit membuat pertanyaan yang serupa ?"

S : "sebenarnya saya bisa bu tapi takut salah"

G : : "lantas kenapa jawabannya kosong sama sekali?"

S : : "karena saya keduluan pusing bu,lalu takut salah dalam menyelesaikannya."

Jawaban Siswa (Berkemampuan Rendah):

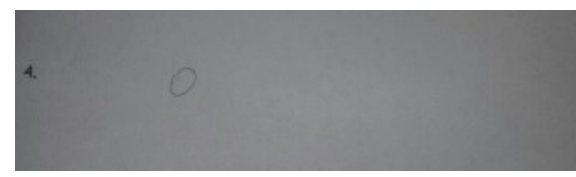




\section{Wawancara:}

G : "kesulitan apa yang kamu hadapi sehingga kamu tidak menuliskan jawaban sama sekali, apakah sulit membuat pertanyaan yang serupa dengan pernyataan tersebut?"

S : "saya bingung bu, sulit memahami soal yang di berikan ibu, karna saya takut salah mau menuliskan jawabannya,jadi saya lewat"

Berdasarkan jawaban siswa I dari hasil wawancara siswa keliru dengan permasalahan dalam soal tersebut siswa kurang mencerna dengan seksama dalam mengubah pertanyaan yang serupa dengan pernyataan tersebut siswa hanya terfokus dengan pertanyaan yang ditanyakan. Oleh karena itu kesimpulannya adalah siswa belum bisa mengembangkan atau mempeluas gagasan dari orang lain.

Untuk jawaban siswa I dan jawaban siswa II hampir sama yaitu siswa belum dapat memahami maksud soal yang ditanyakan siswa keliru dengan pertanyaan yang ditanyakan maka dari itu kemampuan siswa dalam mengembangkan atau memperkaya gagasan orang lain masih dalam tingkatan yang rendah.

Analisis:

Berdasarkan hasil jawaban siswa, maka kesalahan yang dilakukan oleh siswa, siswa belum bisa merubah suatu pertanyaan yang serupa dengan pertanyaan yang diberikan, siswa belum bisa mengembangkan atau memperluas suatu gagasan orang lain, dapat disimpulkan secara keseluruhan bahwa kemampuan berkemampuan tinggi, sedang dan rendah dalam indikator kemampuan berpikir elaborasi tergolong sangat rendah.

\section{KESIMPULAN}

Berdasarkan hasil dan pembahasan, dapat disimpulkan beberapa kesalahan siswa dalam menjawab soal.

a. Kesalahan dengan siswa kurangnya memahami sebuah konsep dalam penyelesaian suatu permasalahan di dalam soal.

b. Kesalahan dengan siswa belum bisa berpikir secara lancar dengan memunculkan banyak ide dalam pemecahan masalah matematika dengan banyak jawaban.

c. Kesalahan dalam berpikir menilai dengan belum bisa memberikan suatu ide yang baru untuk menyelesaikan permasalah atau jawaban yang lain dalam menjawab suatu pertanyaan.

d. Sebagaian besar siswa belum dapat berpikir secara asli yaitu dengan membuat pertanyaan dengan mengaitkan kedalam kehidupan sehari-hari.

Dengan begitu, sesuai dengan hasil analisis dari sampel siswa SMP di Kabupaten Bandung Barat yang berkemampuan tinggi, sedang, dan rendah menunjukan rata-rata tingkat kemampuan berpikir kreatif matematik masih tergolong rendah.

\section{DAFTAR PUSTAKA}

Andiyana, M. A., Maya, R., \& Hidayat, W. (2018). ANALISIS KEMAMPUAN BERPIKIR KREATIF MATEMATIS SISWA SMP PADA MATERI BANGUN RUANG. JPMI (Jurnal Pembelajaran Matematika Inovatif), 1(3). 
Azhari. (2013). Peningkatan Kemampuan Berpikir Kreatif Matematika Siswa Melalui Pendekatan Kontruktivisme Di Kelas VII Sekolah Menengah Pertama (SMP) Negeri 2 Banyumas III. Jurnal Pendidikan Matematika, 7, 2-12.

Choridah, D. T. (2013). Peran pembelajaran berbasis masalah untuk meningkatkan kemampuan komunikasi dan berpikir kreatif serta disposisi matematis siswa sma. Infinity Jurnal, 2(2), 194-202.

Dilla, S. C., Hidayat, W., \& Rohaeti, E. E. (2018). Faktor Gender dan Resiliensi dalam Pencapaian Kemampuan Berpikir Kreatif Matematis Siswa SMA. Journal of Medives, 2(1), 129-136.

Hendriana, H., Rohaeti, E. E., \& Hidayat, W. (2017). Metaphorical Thinking Learning and Junior High School Teachers' Mathematical Questioning Ability. Journal on Mathematics Education, 8(1), 55-64.

Hendriana, H., Hidayat, W., \& Ristiana, M. G. (2018, January). Student teachers' mathematical questioning and courage in metaphorical thinking learning. In Journal of Physics: Conference Series (Vol. 948, No. 1, p. 012019). IOP Publishing.

Hidayat, W. (2011). Meningkatkan Kemampuan Berpikir Kritis dan Kreatif Matematik Siswa Melalui Pembelajaran Kooperatif Think-Talk-Write (TTW) (Doctoral dissertation, Universitas Pendidikan Indonesia).

Hidayat, W. (2012). Meningkatkan Kemampuan Berpikir Kritis dan Kreatif Matematik Siswa SMA Melalui Pembelajaran Kooperatif Think-Talk-Write (TTW). In Seminar Nasional Penelitian, Pendidikan dan Penerapan MIPA.

Hidayat, W. (2017). Adversity Quotient dan Penalaran Kreatif Matematis Siswa SMA dalam Pembelajaran Argument Driven Inquiry pada Materi Turunan Fungsi. KALAMATIKA Jurnal Pendidikan Matematika, 2(1), 15-28.

Hidayat, W., \& Prabawanto, S. (2018, January). Improving students' creative mathematical reasoning ability students through adversity quotient and argument driven inquiry learning. In Journal of Physics: Conference Series (Vol. 948, No. 1, p. 012005). IOP Publishing.

Istianah, E. (2013). Meningkatkan Kemampuan Berpikir Kritis dan Kreatif Matematik dengan Pendekatan Model Eliciting Activities (MEAs) pada S, 2(1), 43-54.

Nurjaman, A., \& Sari, I. P. (2017). The Effect Of Problem Posing Approach Towards Students' Mathematical Disposition, Critical \&Amp; Creative Thinking Ability Based On School Level. Infinity Journal, 6(1), 69. https://doi.org/10.22460/infinity.v6i1.223

Rahman, R. (2012). Hubungan antara self-concept terhadap matematika dengan kemampuan berpikir kreatif matematik siswa, 1(1), 19-30.

Rahmi, S., Nadia, R., Hasibah, B., \& Hidayat, W. (2017). The Relation between Self-Efficacy toward Math with the Math Communication Competence. Infinity Journal, 6(2), 177-182 
Purwasih, R. (2017). Pembelajaran Berbasis Masalah untuk Meningkatkan Kemampuan Berpikir Kreatif dan Self-Concept Siswa SMP. Jurnal Didaktifk Matematika, 4185(1), $15-24$.

Sumarmo, U., Hidayat, W., Zukarnaen, R., Hamidah, M., \& Sariningsih, R. (2012). Kemampuan dan Disposisi Berpikir Logis, Kritis, dan Kreatif Matematik (Eksperimen terhadap Siswa SMA Menggunakan Pembelajaran Berbasis Masalah dan Strategi ThinkTalk-Write). Jurnal Pengajaran MIPA, 17(1), 17-33.

Sumarmo, U., Mulyani, E., \& Hidayat, W. (2018). Mathematical Communication Ability and Self Confidence Experiment with Eleventh Grade Students Using Scientific Approach. JIML-Journal of Innovative Mathematics Learning, 1(1), 19-30.

Tresnawati, T., Hidayat, W., \& Rohaeti, E. E. (2017). Kemampuan Berpikir Kritis Matematis dan Kepercayaan Diri Siswa SMA. Symmetry: Pasundan Journal of Research in Mathematics Learning and Education, 2(2), 39-45. 
